\title{
EFIKASI HERBISIDA PIKLORAM + 2,4 D TERHADAP GULMA PADA BUDIDAYA TANAMAN TEBU (Saccharum officinarum $L$.)
}

\section{EFFICACY OF PICLORAM + 2,4 D HERBICIDE IN CONTROLLING WEEDS IN SUGARCANE PLANTATION (Saccharum officinarum L.)}

\author{
Herry Susanto, Dad Resiworo Jekti Sembodo, Khusni Ekky Susanto dan Sugiatno* \\ Jurusan Agroteknologi Fakultas Pertanian Universitas Lampung, Bandar Lampung, Indonesia \\ *Email:sugiatno.1960@fp.unila.ac.id \\ * Corresponding Author, Diterima: 29 Okt. 2021 , Direvisi: 15 Des. 2021 , Disetujui: 9 Jan. 2022
}

\begin{abstract}
The objectives of this study was to determine dose wich is effective in controlling weeds in sugarcane plantations, changes in weed composition, and whether there is phytotoxicity of sugarcane after application of herbicide picloram $+2,4$ D The research was conducted in the Unila experimental field, Muara Putih Village, Natar District, South Lampung Regency and the Weed Laboratory of the Faculty of Agriculture, University of Lampung, Gedong Meneng, Bandar Lampung starting from December 2017 to March 2018. The study used a randomized block design with four replications and seven treatments, namely the dose of herbicide picloram + 2,4-D 57.5 + 225 g/ha (P1), $86.25+337.5 \mathrm{~g} / \mathrm{ha}(P 2), 115+450 \mathrm{~g} / \mathrm{ha}(\mathrm{P} 3), 143$, $75+562.5 \mathrm{~g} / \mathrm{ha}(\mathrm{P} 4), 172.5+675 \mathrm{~g} / \mathrm{ha}(\mathrm{P5})$, mechanical weeding (P6), and control plot (P7). The results showed that: (1) picloram herbicide $+2.4 \mathrm{D}$ doses $(57.5+225) \mathrm{g} / \mathrm{ha}$ to $(172.5+675) \mathrm{g} / \mathrm{ha}$ were able to control total weed growth at 4 weeks after application (WAA), weeds in the broad leaf group and dominant weeds Richardia brasiliensis and Ludwigia octovalvis at 4, 8, and $12 \mathrm{MSA}$, but herbicide picloram $+2.4 \mathrm{D}$ dose $(57.5+225) \mathrm{g} / \mathrm{ha}$ to $(172.5+675) \mathrm{g} / \mathrm{ha}$ was unable to control the growth of weeds in the grass group at 4.8, and 12 weeks after application (MSA), (2) application of picloram $+2,4-D$ hebicide doses $(57.5+225) \mathrm{g} / \mathrm{h}$ a to $(172,5+675) \mathrm{g} / \mathrm{ha}$ causes a change in weed composition in sugarcane plantations, (3) herbicide picloram $+2,4-D$ dose $(57.5+225) \mathrm{g} / \mathrm{ha}$ to $(172.5+675) \mathrm{g} / \mathrm{ha}$ does not poison the sugarcane plant.
\end{abstract}

Keywords: Herbicide, picloram, sugarcane, weeds, 2,4 D.

\begin{abstract}
ABSTRAK
Penelitian bertujuan untuk mengetahui dosis herbisida pikloram $+2,4 \mathrm{D}$ yang efektif mengendalikan gulma di pertanaman tebu, mengetahui perubahan komposis gulma akibat aplikasi herbisida pikloram $+2,4 \mathrm{D}$, dan mengetahui apakah terjadi fitotoksisitas tanaman tebu setelah aplikasi herbisida pikloram $+2,4 \mathrm{D}$. Penelitian dilakukan di lahan percobaan Unila Desa Muara Putih, Kecamatan Natar Kabupaten Lampung Selatan dan Laboratorium Gulma Fakultas Pertanian Univeritas Lampung, Gedong Meneng, Bandar Lampung dimulai pada bulan Desember 2017 hingga Maret 2018. Penelitian menggunakan rancangan acak kelompok (RAK) dengan empat ulangan dan tujuh perlakuan yaitu dosis herbisida pikloram +2,4-D 57,5 + $225 \mathrm{~g} / \mathrm{ha}(\mathrm{P} 1), 86,25+337,5 \mathrm{~g} /$ ha (P2), $115+450 \mathrm{~g} / \mathrm{ha}(\mathrm{P} 3), 143,75+562,5 \mathrm{~g} / \mathrm{ha}(\mathrm{P} 4), 172,5+675 \mathrm{~g} / \mathrm{ha}(\mathrm{P} 5)$, penyiangan mekanis (P6), dan tanpa pengendalian atau kontrol (P7). Hasil penelitian menunjukkan bahwa : (1) Herbisida pikloram $+2,4 \mathrm{D}$ dosis $(57,5+225) \mathrm{g} /$ ha hingga $(172,5+675) \mathrm{g} /$ ha mampu mengendalikan pertumbuhan gulma total pada 4 minggu setelah aplikasi (MSA), gulma golongan daun lebar serta gulma dominan Richardia brasiliensis dan Ludwigia octovalvis pada 4,8 , dan $12 \mathrm{MSA}$, namun herbisida pikloram $+2,4 \mathrm{D}$ dosis $(57,5+225) \mathrm{g} /$ ha hingga $(172,5+675)$ $\mathrm{g} / \mathrm{ha}$ tidak mampu mengendalikan pertumbuhan gulma golongan rumput pada 4,8 , serta 12 minggu setelah aplikasi (MSA), (2) Aplikasi hebisida pikloram + 2,4-D dosis $(57,5+225) \mathrm{g} / \mathrm{ha}$ hingga $(172,5+675) \mathrm{g} / \mathrm{ha}$ menyebabkan terjadinya perubahan komposisi gulma di pertamanan tebu, (3) Herbisida pikloram + 2,4-D dosis $(57,5+225) \mathrm{g} /$ ha hingga $(172,5+675) \mathrm{g} /$ ha tidak meracuni tanaman tebu.
\end{abstract}

Kata kunci: gulma, herbisida, pikloram, tebu, 2,4 D. 


\section{PENDAHULUAN}

Tebu merupakan tanaman perkebunan utama di Indonesia sebagai penghasil gula pasir. Gula pasir merupakan salah satu bahan pemanis utama yang digunakan masyarakat Indonesia. Kebutuhan gula yang sangat banyak ini belum mampu dipenuhi oleh hasil produksi gula dari perkebunan tebu dalam negeri yang hanya mencapai 2,318 juta ton (BPS, 2017). Namun, produksi dari sektor perkebunan tebu Indonesia belum maksimal salah satunya disebabkan oleh permasalahan gulma.

Gulma merupakan tumbuhan yang mengganggu atau merugikan kepentingan manusia. Adanya gulma dapat menimbulkan persaingan antara tanaman dengan gulma. Persaingan antara gulma dan tanaman mengakibatkan perebutan unsur hara, air, dan cahaya matahari serta menimbulkan kerugian dalam produksi baik kualitas maupun kuantitas. Faktor-faktor yang menentukan tingkat kompetisi gulma adalah jenis gulma, kerapatan gulma, waktu kehadiran gulma, allelokimia, dan kultur teknis yang diterapkan (Sembodo, 2010). Salah satu cara yang dapat digunakan dalam pengendalian gulma pada pertanaman tebu adalah dengan pengendalian dengan menggunakan kombinasi dua herbisida atau lebih. Kombinasi herbisida lebih menguntungkan secara efektivitas dan ekonomis karena herbisida yang digunakan memiliki sprektum pengenlaian yang berbeda sehingga memperluas spektrum pengendalian, serta dosis herbisida yang digunakan lebih rendah, juga secara ekologis karena mampu menghambat terjadinya resistensi gulma akibat penggunaan herbisida dengan cara kerja yang sama secara terus menerus (Sriyani, 2011).

Penelitian ini bertujuan untuk mengetahui dosis herbisida pikloram $+2,4 \mathrm{D}$ yang efektif mengendalikan gulma di perkebunan tebu, dan mengetahui apakah terjadi fitotoksisitas tanaman tebu akibat aplikasi herbisida pikloram $+2,4 \mathrm{D}$.

\section{BAHAN DAN METODE}

Penelitian ini dilaksanakan di kebun percobaan Unila di Desa Muara Putih, Kecamatan Natar, Kabupaten Lampung Selatan dan Laboratorium Gulma Fakultas Pertanian Universitas Lampung Gedong Meneng, Bandar Lampung dimulai Desember 2017 hingga Maret 2018. Bahan yang akan digunakan pada penelitian ini adalah tanaman tebu, pupuk majemuk (Phonska), kantong plastik, kantong kertas, air, dan herbisida berbahan aktif pikloram tri isopropilamina $115 \mathrm{gr} / 1+2,4 \mathrm{D}$ tri isopropilamina $450 \mathrm{~g} / 1$ (TORDON 115/450 SL). Sedangkan peralatan yang digunakan adalah knapsack sprayer, nozel biru, timbangan digital, oven, gelas ukur, meteran, cangkul, sabit dan kuadran besi berukuran $0,5 \mathrm{~m} \times 0,5 \mathrm{~m}$.

Penelitian ini menggunakan rancangan acak kelompok (RAK) dengan 7 taraf perlakuan dan 4 ulangan. Perlakuan tersebut terdiri dari perlakuan herbisida pikloram + 2,4D (57,5+225)- (172,5 + 675) $\mathrm{g} / \mathrm{ha}$, penyiangan mekanis, dan kontrol (tanpa pengendalian gulma). Pengelompokan ditetapkan berdasarkan keseragaman gulma yang berada di

Tabel 1. Kemampuan Herbisida Pikloram + 2,4 D dalam Mengendalikan Pertumbuhan Gulma Total.

\begin{tabular}{|c|c|c|c|c|c|c|}
\hline \multirow[b]{2}{*}{ Perlakuan } & \multicolumn{2}{|r|}{$4 \mathrm{MSA}$} & \multicolumn{2}{|r|}{$8 \mathrm{MSA}$} & \multicolumn{2}{|c|}{$12 \mathrm{MSA}$} \\
\hline & $\begin{array}{l}\text { Data } \\
\text { Asli }\end{array}$ & $\sqrt{(x+0,5)}$ & $\begin{array}{l}\text { Data } \\
\text { Asli }\end{array}$ & $\sqrt{ }(x+0,5)$ & $\begin{array}{l}\text { Data } \\
\text { Asli }\end{array}$ & $\sqrt{ }(x+0,5)$ \\
\hline & & & $\cdots$ & $\left.\mathrm{g} / 0,5 \mathrm{~m}^{2)}\right) \ldots$ & & $\cdots$ \\
\hline $\begin{array}{l}\text { Pikloram + 2,4 D } \\
57,5+225 \mathrm{~g} / \mathrm{ha}\end{array}$ & 238,84 & $15,33 \mathrm{~b}$ & 426,83 & $20,48 \mathrm{a}$ & 182,76 & $13,70 \mathrm{~b}$ \\
\hline $\begin{array}{l}\text { Pikloram }+2,4 \mathrm{D} \\
86,25+337,5 \mathrm{~g} / \mathrm{ha}\end{array}$ & 203,84 & $14,05 \mathrm{~b}$ & 427,31 & $20,67 \mathrm{a}$ & 185,3 & $13,55 \mathrm{~b}$ \\
\hline $\begin{array}{l}\text { Pikloram + 2,4 D } \\
115+450 \mathrm{~g} / \mathrm{ha}\end{array}$ & 241,16 & $15,47 \mathrm{~b}$ & 540,78 & 23,08 a & 167,46 & $12,69 \mathrm{~b}$ \\
\hline $\begin{array}{l}\text { Pikloram + 2,4 D } \\
143,75+562,5 \mathrm{~g} / \mathrm{ha}\end{array}$ & 195,62 & $13,95 \mathrm{~b}$ & 454,27 & $21,26 \mathrm{a}$ & 190,58 & $13,73 \mathrm{~b}$ \\
\hline $\begin{array}{l}\text { Pikloram + 2,4 D } \\
172,5+675 \mathrm{~g} / \mathrm{ha}\end{array}$ & 149,05 & $12,20 \mathrm{bc}$ & 449,43 & $20,98 \mathrm{a}$ & 122,69 & $12,10 \mathrm{~b}$ \\
\hline Mekanis & 80,52 & $8,51 \mathrm{c}$ & 63,24 & $7,84 \mathrm{~b}$ & 51,4 & $6,83 \quad \mathrm{c}$ \\
\hline Kontrol & 390,29 & 19,43 a & 557,53 & $23,52 \mathrm{a}$ & 270,86 & 16,41 a \\
\hline BNT 5\% & & 3,83 & & 3,94 & & 2,49 \\
\hline
\end{tabular}

Keterangan : Nilai tengah pada setiap kolom yang diikuti huruf yang sama tidak berbeda nyata menurut uji BNT pada taraf $5 \%$. 
petak percobaan.Untuk menguji homogenitas ragam data digunakan uji Bartlett dan additivitas data diuji dengan menggunakan uji Tukey. Jika asumsi terpenuhi, maka data dianalisis dengan sidik ragam dan untuk menguji perbedaan nilai tengah perlakuan diuji dengan uji Beda Nyata Terkecil (BNT) pada taraf 5\%.Satuan petak berukuran luas $5 \mathrm{~m} \times 7 \mathrm{~m}$ (luas $35 \mathrm{~m} 2$ ). Petak lahan yang digunakan kondisi penutupan gulmanya $>75 \%$. Terdapat 28 satuan percobaan yang terdiri dari 7 perlakuan dan 4 ulangan.

Sebelum aplikasi herbisida, dilakukan kalibrasi alat semprot untuk menentukan volume semprot. Pengambilan sampel gulma dilakukan untuk menentukan dan menganalisis efikasi herbisida serta summed dominance ratio (SDR). Pengambilan sampel gulma menggunakan kuadran berukuran $0,5 \mathrm{~m} \times 0,5 \mathrm{~m}$ secara silang, diharapkan gulma yang diambil dapat mewakili kondisi gulma yang sebenarnya. Waktu pengambilan sampel gulma untuk data biomassa dilakukan pada 4, 8 , dan 12 (MSA). Pengamatan bobot kering gulma dilakukan dengan memotong gulma tepat setinggi permukaan tanah pada petak sampel seluas $0,5 \mathrm{~m}$ x $0,5 \mathrm{~m}$ kemudian gulma dipilah sesuai jenisnya. Lalu gulma dikeringkan dengan cara dioven selama 48 jam dengan suhu konstan $80^{\circ} \mathrm{C}$ hingga mencapai bobot yang konstan dan kemudian ditimbang.

Bobot kering dianalisis secara statistika, dari hasil pengolahan data tersebut diperoleh kesimpulan mengenai keberhasilan efikasi herbisida yang digunakan pada percobaan. Bobot kering gulma yang diamati yaitu bobot kering gulma total, gulma pergolongan, dan gulma dominan. Jika nilai $\mathrm{C} \geq 75 \%$ berarti komunitas gulma yang dibanding-kan dianggap sama (Tjitrosoedirdjo dkk, 1984).

\section{HASIL DAN PEMBAHASAN}

\subsection{Bobot Kering Gulma Total}

Hasil Penelitian (Tabel 1) menunjukkan bahwa aplikasi herbisida pikloram $+2,4 \mathrm{D}$ pada pertanaman tebu dengan berbagai taraf dosis mulai dari $(57,5+225) \mathrm{g} /$ ha hingga $(172,5+675) \mathrm{g} / \mathrm{ha}$ mampu mengendalikan gulma total pada 4 dan 12 Minggu Setelah Aplikasi (MSA), herbisida pikloram $+2,4$ D tidak mampu mengendalikan bobot kering gulma total disemua taraf dosis perlakuan pada 8 MSA. Herbisida yang digunakan adalah herbisida selektif daun lebar sehingga gulma rumput dan teki tidak terkendali. Selektifitas herbisida merupakan daya kendali herbisida pada salah satu jenis tumbuhan/ gulma dan tidak merusak tanaman yang dibudidayakan (Moenandir, 1990).

\subsection{Bobot Kering Gulma Daun Lebar}

Hasil penelitian (Tabel 2) menunjukkan Herbisida pikloram $+2,4$ D pada semua dosis perlakuan dapat mengendalikan gulma golongan daun lebar mulai dari 4 MSA hingga 12 MSA. Hal

Tabel 2. Kemampuan Herbisida Pikloram +2,4 D dalam Mengendalikan Pertumbuhan Gulma daun Lebar.

\begin{tabular}{|c|c|c|c|c|c|c|}
\hline \multirow[b]{2}{*}{ Perlakuan } & \multicolumn{2}{|r|}{$4 \mathrm{MSA}$} & \multicolumn{2}{|r|}{$8 \mathrm{MSA}$} & \multicolumn{2}{|r|}{12 MSA } \\
\hline & $\begin{array}{l}\text { Data } \\
\text { Asli }\end{array}$ & $\sqrt{\sqrt{ }}(x+0,5)$ & $\begin{array}{l}\text { Data } \\
\text { Asli }\end{array}$ & $\sqrt{ } \sqrt{ }(x+0,5)$ & $\begin{array}{l}\text { Data } \\
\text { Asli }\end{array}$ & $\sqrt{ } \sqrt{(x+0,5)}$ \\
\hline & & & 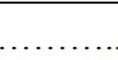 & $\left.\mathrm{g} / 0,5 \mathrm{~m}^{2)}\right) \ldots \ldots \ldots$ & & \\
\hline $\begin{array}{l}\text { Pikloram + 2,4 D } \\
57,5+225 \mathrm{~g} / \mathrm{ha} \\
\text { Pikloram + 2,4 D }\end{array}$ & 28,01 & $1,46 \mathrm{~b}$ & 9,91 & $1,64 \mathrm{c}$ & 31,24 & $2,06 \mathrm{~b}$ \\
\hline $\begin{array}{l}86,25+337,5 \mathrm{~g} / \mathrm{ha} \\
\text { Pikloram + 2,4 D }\end{array}$ & 16,08 & $1,34 \mathrm{~b}$ & 7,51 & $1,61 \mathrm{c}$ & 8,94 & $1,46 \mathrm{c}$ \\
\hline $\begin{array}{l}115+450 \mathrm{~g} / \mathrm{ha} \\
\text { Pikloram }+2,4 \mathrm{D}\end{array}$ & 9,75 & $1,21 \mathrm{bc}$ & 0,33 & $0,93 \mathrm{~d}$ & 0,87 & $0,89 \mathrm{~d}$ \\
\hline $\begin{array}{l}143,75+562,5 \mathrm{~g} / \mathrm{ha} \\
\text { Pikloram }+2,4 \mathrm{D}\end{array}$ & 7,45 & $1,27 \mathrm{bc}$ & 0 & $0,84 \mathrm{~d}$ & 0 & $0,84 \mathrm{~d}$ \\
\hline $172,5+675 \mathrm{~g} / \mathrm{ha}$ & 1,85 & $1,01 \mathrm{c}$ & 0 & $0,84 \mathrm{~d}$ & 0 & $0,84 \mathrm{~d}$ \\
\hline Mekanis & 27,41 & $1,47 \mathrm{~b}$ & 53,98 & $2,65 \mathrm{~b}$ & 29,22 & $2,15 \mathrm{~b}$ \\
\hline Kontrol & 241,16 & $1,91 \mathrm{a}$ & 447,31 & $4,58 \mathrm{a}$ & 184,2 & $3,67 \mathrm{a}$ \\
\hline BNT $5 \%$ & & 0,31 & & 0,45 & & 0,50 \\
\hline
\end{tabular}

Keterangan : Nilai tengah pada setiap kolom yang diikuti huruf yang sama tidak berbeda nyata menurut uji BNT pada taraf $5 \%$. 
ini ditunjukkan dengan bobot kering gulma perlakuan herbisida pikloram $+2,4 \mathrm{D}$ lebih rendah dibandingkan pengendalian mekanis dan kontrol (Tabel 2).

\subsection{Bobot Kering Gulma Rumput}

Hasil penelitian (Tabel 3) menunjukkan herbisida pikloram $+2,4 \mathrm{D}$ pada semua taraf dosis perlakuan tidak mampu mengendalikan pertumbuhan gulma golongan rumput pada 4,8, 12 MSA. Kemampuan herbisida pikloram $+2,4 \mathrm{D}$ dalam mengendalikan gulma rumput tidak sebaik dalam mengendalikan gulma daun lebar. Hal ini dikarenakan adanya perbedaan morfologis dari gulma golongan daun lebar dan rumput yang mempengaruhi selektifitas herbisida campuran. Menurut Moenandir (1990), perbedaan morfologis dapat mempengaruhi selektifitas herbisida.

Pada gulma golongan daun lebar, mempunyai meristem pada ujung tumbuhan yang dapat langsung terkena herbisida sehingga gulma daun lebar menjadi lebih peka terhadap herbisida. Sementara pada gulma berdaun sempit seperti rumput memiliki meristem yang terlindung sehingga menjadi kurang peka terhadap herbisida. Menurut Sembodo (2010), herbisida yang telah masuk dalam sel, sebagian ada yang tidak mobil dan yang lainnya dapat ditranslokasikan ke sel-sel lainnya. Sifat mobilitas

Tabel 3. Pengaruh Perlakuan Herbisida Pikloram + 2,4 D terhadap Bobot Kering Gulma Rumput.

\begin{tabular}{|c|c|c|c|c|c|c|}
\hline \multirow{2}{*}{ Perlakuan } & \multicolumn{2}{|c|}{4 MSA } & \multicolumn{2}{|c|}{$8 \mathrm{MSA}$} & \multicolumn{2}{|r|}{$12 \mathrm{MSA}$} \\
\hline & Data Asli & $\sqrt{\sqrt{ }(x+0,5)}$ & Data Asli & $\sqrt{(x+0,5)}$ & Data Asli & $\sqrt{(x+0,5)}$ \\
\hline Pikloram + 2,4 D & & & & $\left./ 0,5 \mathrm{~m}^{2)}\right) \ldots \ldots \ldots$ & & \\
\hline $\begin{array}{l}57,5+225 \mathrm{~g} / \mathrm{ha} \\
\text { Pikloram }+2,4 \mathrm{D}\end{array}$ & 124,2 & $3,28 \mathrm{abc}$ & 385,76 & $19,27 \mathrm{ab}$ & 151,51 & $12,91 \mathrm{a}$ \\
\hline $\begin{array}{l}86,25+337,5 \mathrm{~g} / \mathrm{ha} \\
\text { Pikloram }+2,4 \mathrm{D}\end{array}$ & 154,95 & $3,46 \mathrm{abc}$ & 382,84 & $19,57 \mathrm{ab}$ & 176,26 & $13,26 \mathrm{a}$ \\
\hline $\begin{array}{l}115+450 \mathrm{~g} / \mathrm{ha} \\
\text { Pikloram }+2,4 \mathrm{D}\end{array}$ & 168,69 & $3,52 \mathrm{ab}$ & 500,76 & $22,26 \mathrm{a}$ & 166,06 & $13,66 \mathrm{a}$ \\
\hline $\begin{array}{l}143,75+562,5 \mathrm{~g} / \mathrm{ha} \\
\text { Pikloram }+2,4 \mathrm{D}\end{array}$ & 180,76 & $3,65 \mathrm{a}$ & 411,44 & $20,25 \mathrm{ab}$ & 190,5 & $13,73 \mathrm{a}$ \\
\hline $172,5+675 \mathrm{~g} / \mathrm{ha}$ & 90,29 & $3,01 \mathrm{bc}$ & 344,96 & $18,44 \mathrm{~b}$ & 120,14 & $11,99 \mathrm{a}$ \\
\hline Mekanis & 1,97 & $1,15 \mathrm{~d}$ & 3,31 & $1,77 \mathrm{~d}$ & 19,51 & $4,14 \mathrm{c}$ \\
\hline Kontrol & 90,02 & $2,95 \mathrm{c}$ & 78,99 & $8,90 \quad \mathrm{c}$ & 85,98 & $8,93 \mathrm{~b}$ \\
\hline BNT 5\% & & 0,51 & & 3,40 & & 2,91 \\
\hline
\end{tabular}

Keterangan : Nilai tengah pada setiap kolom yang diikuti huruf yang sama tidak berbeda nyata menurut uji BNT pada taraf $5 \%$.

Tabel 4. Pengaruh Perlakuan Herbisida Pikloram + 2,4 D terhadap Bobot Kering Gulma Teki.

\begin{tabular}{|c|c|c|c|c|c|c|}
\hline \multirow{2}{*}{ Perlakuan } & \multicolumn{2}{|r|}{4 MSA } & \multicolumn{2}{|r|}{8 MSA } & \multicolumn{2}{|r|}{$12 \mathrm{MSA}$} \\
\hline & Data Asli & $\sqrt{ } \sqrt{(x+0,5)}$ & Data Asli & $\sqrt{\sqrt{ }(x+0,5)}$ & Data Asli & $\sqrt{\sqrt{ }(x+0,5)}$ \\
\hline & & & & $\left.\mathrm{g} / 0,5 \mathrm{~m}^{2)}\right) \ldots \ldots \ldots$ & & \\
\hline $\begin{array}{l}\text { Pikloram + 2,4 D } \\
57,5+225 \text { g/ha } \\
\text { Pikloram + 2,4 D }\end{array}$ & 86,63 & $3,00 \mathrm{a}$ & 31,15 & $1,47 \mathrm{a}$ & 0 & $0,84 \mathrm{~b}$ \\
\hline $\begin{array}{l}86,25+337,5 \mathrm{~g} / \mathrm{ha} \\
\text { Pikloram }+2,4 \mathrm{D}\end{array}$ & 32,81 & $2,33 \mathrm{ab}$ & 36,96 & $1,54 \mathrm{a}$ & 0,09 & $0,87 \mathrm{~b}$ \\
\hline $\begin{array}{l}115+450 \mathrm{~g} / \mathrm{ha} \\
\text { Pikloram }+2,4 \mathrm{D}\end{array}$ & 62,7 & $2,61 \mathrm{a}$ & 39,68 & $1,51 \mathrm{a}$ & 0,51 & $0,98 \mathrm{~b}$ \\
\hline $\begin{array}{l}143,75+562,5 \mathrm{~g} / \mathrm{ha} \\
\text { Pikloram }+2,4 \mathrm{D}\end{array}$ & 7,40 & $1,53 \mathrm{~b}$ & 42,83 & $1,47 \mathrm{a}$ & 0,07 & $0,86 \mathrm{~b}$ \\
\hline $172,5+675 \mathrm{~g} / \mathrm{ha}$ & 56,90 & $2,56 \mathrm{a}$ & 104,47 & $1,61 \mathrm{a}$ & 2,55 & $1,25 \mathrm{a}$ \\
\hline Mekanis & 4,47 & $2,41 \mathrm{c}$ & 5,94 & $1,25 \mathrm{a}$ & 2,66 & $1,37 \mathrm{a}$ \\
\hline Kontrol & 59,11 & $2,55 \mathrm{a}$ & 31,23 & $1,47 \mathrm{a}$ & 0,67 & $0,99 \mathrm{~b}$ \\
\hline BNT 5\% & & 0,86 & & 0,42 & & 0,21 \\
\hline
\end{tabular}

Keterangan : Nilai tengah pada setiap kolom yang diikuti huruf yang sama tidak berbeda nyata menurut uji BNT pada taraf $5 \%$. 
herbisida dalam sel ini juga memiliki kontribusi terhadap selektivitas herbisida, serta beberapa tumbuhan dapat mendetoksifikasi (membuat tidak beracun) herbisida yang diaplikasikan.

\subsection{Bobot Kering Gulma Teki}

Hasil penelitian (Tabel 4) menunjukkan bahwa herbisida pikloram $+2,4$ D pada 4 MSA dosis $(143,75+562,5) \mathrm{g} / \mathrm{ha}$ mampu mengendalikan gulma teki sedangkan dosis herbisida campuran lainnya tidak dapat mengendalikan gulma teki, namun tidak berbeda nyata dengan perlakuan dosis
$(86,24+337,5) \mathrm{g} / \mathrm{ha}$. Herbisida pikloram $+2,4 \mathrm{D}$ pada 8 dan 12 MSA tidak dapat mengendalikan gulma teki.

\subsection{Bobot Kering Gulma Richardia brasiliensis}

Hasil penelitian (Tabel 5) menunjukkan Gulma Richardia brasiliensis merupakan gulma yang mendominasi pada petak percobaan. Herbisida pikloram $+2,4$ D pada dosis $(57,5+$ $225) \mathrm{g} /$ ha sampai $(172,5+675) \mathrm{g} / \mathrm{ha}$ mampu mengendalikan gulma Richardia brasiliensis pada 4,8 , dan 12 MSA.

Tabel 5. Pengaruh Perlakuan Herbisida Pikloram + 2,4 D terhadap Bobot Kering Gulma Richardia brasiliensis

\begin{tabular}{|c|c|c|c|c|c|c|}
\hline \multirow{2}{*}{ Perlakuan } & \multicolumn{2}{|r|}{4 MSA } & \multicolumn{2}{|c|}{8 MSA } & \multicolumn{2}{|c|}{12 MSA } \\
\hline & $\begin{array}{l}\text { Data } \\
\text { Asli }\end{array}$ & $\sqrt{ } \sqrt{ }(x+0,5)$ & $\begin{array}{l}\text { Data } \\
\text { Asli }\end{array}$ & $\sqrt{\sqrt{ }}(x+0,5)$ & $\begin{array}{l}\text { Data } \\
\text { Asli }\end{array}$ & $\sqrt{ } \sqrt{ }(x+0,5)$ \\
\hline & & & ( & $\left.0,5 \mathrm{~m}^{2)}\right) \ldots \ldots \ldots \ldots$ & & \\
\hline \multicolumn{7}{|l|}{ Pikloram + 2,4 D } \\
\hline $\begin{array}{l}57,5+225 \mathrm{~g} / \mathrm{ha} \\
\text { Pikloram }+2,4 \mathrm{D}\end{array}$ & 13,98 & $1,23 \mathrm{bc}$ & 0 & $0,91 \mathrm{c}$ & 13,34 & $1,28 \mathrm{~b}$ \\
\hline $86,25+337,5 \mathrm{~g} / \mathrm{ha}$ & 1,77 & $1,06 \mathrm{~cd}$ & 0 & $0,91 \mathrm{c}$ & 8,04 & $1,15 \mathrm{bc}$ \\
\hline Pikloram + 2,4 D & & & & & & \\
\hline $115+450 \mathrm{~g} / \mathrm{ha}$ & 0 & $0,91 \mathrm{~d}$ & 0 & $0,91 \mathrm{c}$ & 0 & $0,91 \mathrm{c}$ \\
\hline $\begin{array}{l}\text { Pikloram + 2,4 D } \\
143,75+562,5 \mathrm{~g} / \mathrm{ha}\end{array}$ & 0 & 001 & 0 & $091 \mathrm{c}$ & 0 & $0.91 \mathrm{c}$ \\
\hline $\begin{array}{l}\text { Pikloram + 2,4 D } \\
\text { Piklom }\end{array}$ & 0 & $0,91 \quad \mathrm{~d}$ & 0 & $0,91 \mathrm{c}$ & 0 & $0,91 \mathrm{c}$ \\
\hline $172,5+675 \mathrm{~g} / \mathrm{ha}$ & 0 & $0,91 \mathrm{~d}$ & 0 & $0,91 \mathrm{c}$ & 0 & $0,91 \mathrm{c}$ \\
\hline Mekanis & 20,59 & $1,43 \mathrm{ab}$ & 13,963 & $1,29 \mathrm{~b}$ & 13,665 & $1,24 \mathrm{~b}$ \\
\hline Kontrol & 82,54 & $1,58 \mathrm{a}$ & 139,74 & $1,73 \mathrm{a}$ & 52,765 & $1,63 \mathrm{a}$ \\
\hline BNT 5\% & & 0,29 & & 0,23 & & 0,27 \\
\hline
\end{tabular}

Keterangan : Nilai tengah pada setiap kolom yang diikuti huruf yang sama tidak berbeda nyata menurut uji BNT pada taraf $5 \%$.

Tabel 6. Pengaruh Perlakuan Herbisida Pikloram +2,4 D terhadap Bobot Kering Gulma Ludwigia octovalvis.

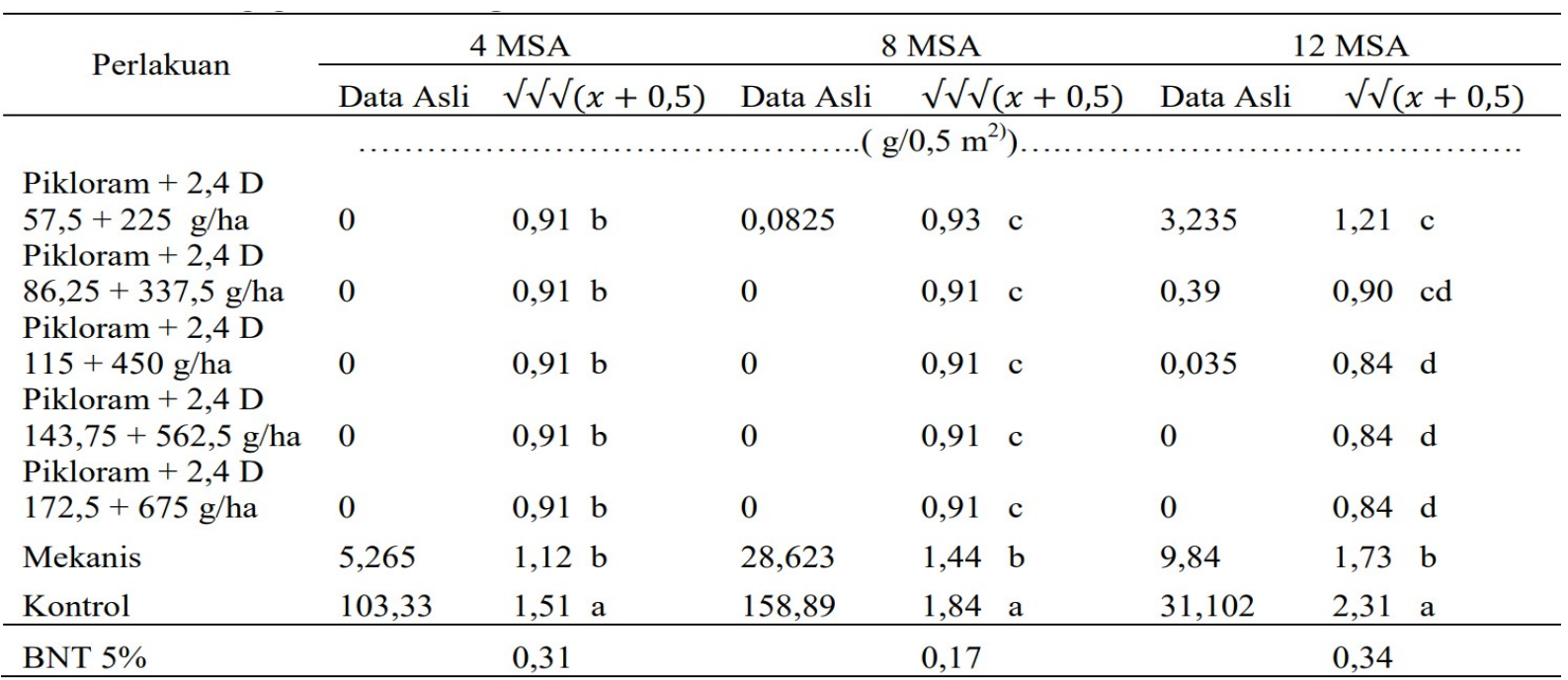

Keterangan : Nilai tengah pada setiap kolom yang diikuti huruf yang sama tidak berbeda nyata menurut uji BNT pada taraf $5 \%$. 


\subsection{Bobot Kering Gulma Ludwigia octovalvis}

Hasil penelitian (Tabel 6) menunjukkan bahwa herbisida pikloram $+2,4 \mathrm{D}$ dosis $(57,5+225) \mathrm{g} / \mathrm{ha}$ sampai $(172,5+675) \mathrm{g} /$ ha mampu mengendalikan gulma Ludwigia octovalvis pada 4 dan 8 MSA dan daya kendali antar dosis herbisida campuran sama. Pada 12 MSA herbisida pikloram + 2,4 D pada setiap dosis perlakuan mampu mengendalikan perumbuhan gulma.

\subsection{Bobot Kering Gulma Dactyloctenium aegyptum}

Hasil penelitian (Tabel 7) menunjukkan herbisida pikloram $+2,4 \mathrm{D}$ dosis $(57,5+225)$ sampai $(172,5+675) \mathrm{g} / \mathrm{ha}$ tidak mampu mengendalikan gulma Dactyloctenium aegyptum pada 4, 8, dan 12 MSA. Pada perlakuan penyiangan mekanis mampu mengendalikan gulma Dactyloctenium aegyptum hingga $12 \mathrm{MSA}$. Hal ini berarti perlakuan

Tabel 7. Pengaruh Perlakuan Herbisida Pikloram + 2,4 D terhadap Bobot Kering Gulma Dactyloctenium aegyptum.

\begin{tabular}{|c|c|c|c|c|c|c|}
\hline \multirow{2}{*}{ Perlakuan } & \multicolumn{2}{|c|}{4 MSA } & \multicolumn{2}{|c|}{8 MSA } & \multicolumn{2}{|c|}{12 MSA } \\
\hline & Data Asli & $\sqrt{ } \sqrt{ }(x+0,5)$ & Data Asli & $\sqrt{ }(x+0,5)$ & Data Asli & $\sqrt{ }(x+0,5)$ \\
\hline & & & ............ ( & $\left(0,5 \mathrm{~m}^{2)}\right) \ldots \ldots \ldots$ & & \\
\hline $\begin{array}{l}\text { Pikloram + 2,4 D } \\
57,5+225 \mathrm{~g} / \mathrm{ha} \\
\text { Pikloram + 2,4 D }\end{array}$ & 52,87 & $2,76 \mathrm{ab}$ & 197,03 & 3,68 a & 105,53 & 3,28 a \\
\hline $\begin{array}{l}86,25+337,5 \mathrm{~g} / \mathrm{ha} \\
\text { Pikloram + 2,4 D }\end{array}$ & 16,68 & $2,07 \mathrm{bc}$ & 197,36 & $3,62 \mathrm{a}$ & 106,24 & 3,12 a \\
\hline $\begin{array}{l}115+450 \mathrm{~g} / \mathrm{ha} \\
\text { Pikloram + } 2,4 \mathrm{D}\end{array}$ & 45,09 & $2,42 \mathrm{ab}$ & 222,34 & 3,75 a & 71,58 & $2,77 \mathrm{a}$ \\
\hline $\begin{array}{l}143,75+562,5 \mathrm{~g} / \mathrm{ha} \\
\text { Pikloram }+2,4 \mathrm{D}\end{array}$ & 89,145 & 3,11 a & 338,65 & $4,26 \mathrm{a}$ & 100,39 & $3,10 \mathrm{a}$ \\
\hline $172,5+675 \mathrm{~g} / \mathrm{ha}$ & 66,935 & $2,91 \quad \mathrm{a}$ & 301,46 & $4,14 \mathrm{a}$ & 99,01 & 3,32 a \\
\hline Mekanis & 1,965 & $1,36 \mathrm{c}$ & 1,92 & $1,18 \mathrm{c}$ & 3,59 & $1,23 \mathrm{~b}$ \\
\hline Kontrol & 51,3 & $2,64 \mathrm{ab}$ & 66,5 & $2,85 \mathrm{~b}$ & 55,77 & $2,68 \mathrm{a}$ \\
\hline BNT 5\% & & 0,80 & & 0,66 & & 0,64 \\
\hline
\end{tabular}

Keterangan : Nilai tengah pada setiap kolom yang diikuti huruf yang sama tidak berbeda nyata menurut uji BNT pada taraf $5 \%$.

Tabel 8. Pengaruh Perlakuan Herbisida Pikloram + 2,4 D terhadap Bobot Kering Gulma Digitaria ciliaris

\begin{tabular}{|c|c|c|c|c|c|c|}
\hline \multirow{2}{*}{ Perlakuan } & \multicolumn{2}{|l|}{4 MSA } & \multicolumn{2}{|c|}{8 MSA } & \multicolumn{2}{|c|}{$12 \mathrm{MSA}$} \\
\hline & Data Asli & $\sqrt{ } \sqrt{ }(x+0,5)$ & Data Asli & $\sqrt{ } \sqrt{ }(x+0,5)$ & Data Asli & $\sqrt{ } \sqrt{ }(x+0,5)$ \\
\hline & & & ............. (g & $\left(0,5 \mathrm{~m}^{2)}\right) \ldots \ldots \ldots$ & & \\
\hline $\begin{array}{l}\text { Pikloram + 2,4 D } \\
57,5+225 \mathrm{~g} / \mathrm{ha} \\
\text { Pikloram }+2,4 \mathrm{D}\end{array}$ & 58,21 & $1,51 \mathrm{abc}$ & 140,81 & $3,26 \mathrm{ab}$ & 24,33 & $1,46 \mathrm{ab}$ \\
\hline $\begin{array}{l}86,25+337,5 \mathrm{~g} / \mathrm{ha} \\
\text { Pikloram + } 2,4 \mathrm{D}\end{array}$ & 118,91 & $1,75 \mathrm{a}$ & 137,3 & $3,31 \mathrm{ab}$ & 27,37 & $1,49 \mathrm{ab}$ \\
\hline $\begin{array}{l}115+450 \mathrm{~g} / \mathrm{ha} \\
\text { Pikloram }+2,4 \mathrm{D}\end{array}$ & 76,44 & $1,64 \mathrm{abc}$ & 172,46 & 3,55 a & 69,715 & $1,74 \mathrm{a}$ \\
\hline $\begin{array}{l}143,75+562,5 \mathrm{~g} / \mathrm{ha} \\
\text { Pikloram }+2,4 \mathrm{D}\end{array}$ & 90,57 & $1,68 \mathrm{ab}$ & 65,02 & $2,69 \mathrm{bc}$ & 23,74 & $1,41 \mathrm{~b}$ \\
\hline $172,5+675 \mathrm{~g} / \mathrm{ha}$ & 23,35 & $1,27 \mathrm{~cd}$ & 34,92 & $2,36 \mathrm{c}$ & 8,14 & $1,21 \quad b c$ \\
\hline Mekanis & 0 & $0,91 \quad \mathrm{~d}$ & 1,04 & $1,04 \mathrm{~d}$ & 1,5 & $1,03 \mathrm{c}$ \\
\hline Kontrol & 34,20 & $1,29 \mathrm{bcd}$ & 5,6 & $1,43 \mathrm{~d}$ & 15,97 & $1,23 \mathrm{bc}$ \\
\hline BNT 5\% & & 0,39 & & 0,66 & & 0,30 \\
\hline
\end{tabular}

Keterangan : Nilai tengah pada setiap kolom yang diikuti huruf yang sama tidak berbeda nyata menurut uji BNT pada taraf 5\%. 
herbisida tidak lebih baik dibandingkan perlakuan penyiangan mekanis dalam mengendalikan gulma Dactyloctenium aegyptum.

\subsection{Bobot Kering Digitaria ciliaris}

Hasil penelitian (Tabel 8) menunjukkan bahwa herbisida pikloram $+2,4 \mathrm{D}$ dosis $(57,5+225)$ sampai $(172,5+675) \mathrm{g} / \mathrm{ha}$ tidak mampu mengendalikan gulma Digitaria ciliaris pada 4, 8, dan 12 MSA (Tabel 10). Pada perlakuan penyiangan mekanis mampu mengendalikan gulma Digitaria ciliaris hingga 12 MSA. Hal ini berarti perlakuan herbisida tidak lebih baik dibandingkan perlakuan penyiangan mekanis dalam mengendalikan gulma Digitaria ciliaris.

\subsection{Bobot Kering Gulma Cyperus iria}

Hasil penelitian (Tabel 9) menunjukan herbisida pikloram $+2,4 \mathrm{D}$ dosis $(57,5+225) \mathrm{g} /$ ha sampai $(172,5+675) \mathrm{g} / \mathrm{ha}$ tidak mampu mengendalikan gulma Cyperus iria pada 4 dan 8 MSA. Perlakuan herbisida pikloram $+2,4 \mathrm{D}$ dosis $(57,5+225) \mathrm{g} /$ ha sampai $(143,75+562,5) \mathrm{g} / \mathrm{ha}$ mampu mengendalikan gulma Cyperus iria pada 12 MSA. Perlakuan herbisida dosis $(172,5+675) \mathrm{g} /$ ha tidak mampu mengendalikan gulma Cyperus iria pada 12 MSA. Perlakuan penyiangan mekanis tidak dapat mengendalikan pertumbuhan gulma pada 4 MSA disebabkan pengambilan sampel dilakukan sebelum dilakukannya penyiangan.

Tabel 9. Pengaruh Perlakuan Herbisida Pikloram + 2,4 D terhadap Bobot Kering Gulma Cyperus iria.

\begin{tabular}{|c|c|c|c|c|c|c|}
\hline \multirow{2}{*}{ Perlakuan } & \multicolumn{2}{|c|}{4 MSA } & \multicolumn{2}{|c|}{$8 \mathrm{MSA}$} & \multicolumn{2}{|c|}{$12 \mathrm{MSA}$} \\
\hline & Data Asli & $\sqrt{\sqrt{ }}(x+0,5)$ & Data Asli & $\sqrt{\sqrt{ }}(x+0,5)$ & Data Asli & $\sqrt{ } \sqrt{(x+0,5)}$ \\
\hline & & & $\ldots \ldots \ldots(\mathrm{g} /$ &, $\left.5 \mathrm{~m}^{2)}\right) \ldots \ldots \ldots \ldots$ & & \\
\hline \multicolumn{7}{|l|}{ Pikloram + 2,4 D } \\
\hline $\begin{array}{l}57,5+225 \mathrm{~g} / \mathrm{ha} \\
\text { Pikloram }+2,4 \mathrm{D}\end{array}$ & 86,63 & $1,73 \mathrm{a}$ & 31,15 & $1,40 \mathrm{a}$ & 0 & $0,84 \mathrm{~b}$ \\
\hline $\begin{array}{l}86,25+337,5 \mathrm{~g} / \mathrm{ha} \\
\text { Pikloram + 2,4 D }\end{array}$ & 22,04 & $1,52 \mathrm{ab}$ & 36,96 & $1,54 \mathrm{a}$ & 0,09 & $0,87 \mathrm{~b}$ \\
\hline $\begin{array}{l}115+450 \mathrm{~g} / \mathrm{ha} \\
\text { Pikloram }+2,4 \mathrm{D}\end{array}$ & 62,72 & $1,60 \mathrm{a}$ & 39,68 & $1,51 \mathrm{a}$ & 0,51 & $0,98 \mathrm{~b}$ \\
\hline $\begin{array}{l}143,75+562,5 \mathrm{~g} / \mathrm{ha} \\
\text { Pikloram + 2,4 D }\end{array}$ & 7,402 & $1,22 \mathrm{~b}$ & 42,83 & $1,47 \mathrm{a}$ & 0,07 & $0,86 \mathrm{~b}$ \\
\hline $172,5+675 \mathrm{~g} / \mathrm{ha}$ & 41,255 & 1,58 a & 104,47 & 1,61 a & 2,55 & 1,25 a \\
\hline Mekanis & 51,142 & $1,53 \mathrm{a}$ & 5,94 & $1,25 \mathrm{a}$ & 2,66 & $1,37 \mathrm{a}$ \\
\hline Kontrol & 59,11 & $1,58 \mathrm{a}$ & 31,23 & $1,47 \mathrm{a}$ & 0,67 & $0,99 \mathrm{~b}$ \\
\hline BNT 5\% & & 0,30 & & 0,42 & & 0,21 \\
\hline
\end{tabular}

Keterangan : Nilai tengah pada setiap kolom yang diikuti huruf yang sama tidak berbeda nyata menurut uji BNT pada taraf $5 \%$.

Tabel 10. Perubahan Komposisi Jenis Gulma pada 4 - 12 MSA (\%).

\begin{tabular}{lrrrr}
\hline \multirow{2}{*}{ Perbandingan } & & \multicolumn{2}{c}{ Nilai Koefisien Komunitas (\%) } \\
\cline { 3 - 5 } & & 4 MSA & 8 MSA & 12 MSA \\
\hline Pikloram + 2,4 D 57,5+225 g/ha & vs Kontrol & 52 & 44 & 58 \\
Pikloram + 2,4 D 86,25 + 337,5 g/ha & vs Kontrol & 45 & 36 & 44 \\
Pikloram + 2,4 D 115+450 g/ha & vs Kontrol & 44 & 31 & 39 \\
Pikloram + 2,4 D 143,75 + 562,5 g/ha vs Kontrol & 33 & 25 & 34 \\
Pikloram + 2,4 D 172,5 + 675 g/ha & vs Kontrol & 36 & 26 & 30 \\
Mekanis & & 55 & 75 & 63 \\
\hline
\end{tabular}




\subsection{Koefisien Komunitas dan Perubahan Komposisi}

Menurut Sastroutomo (1992), dalam Alfredo (2012), perubahan komposisi gulma terjadi karna tekanan selektifitas yang tinggi dari herbisida yang digunakan serta perbedaan tanggapan dari masingmasing jenis gulma terhadap herbisida. Menurut Tjitrosoedirdjo dkk. (1984), jika nilai perbandingan dua komunitas lebih dari 75\% maka dua komunitas tersebut dianggap memiliki komposisi gulma yang sama.

Berdasarkan hasil pengamatan 4, 8 dan 12 MSA, diketahui terjadi perubahan komposisi antara 2 komunitas gulma yang dibandingkan. Perlakuan herbisida pikloram $+2,4 \mathrm{D}$ dosis $57,5+225 \mathrm{~g} / \mathrm{ha}$ $172,5+675 \mathrm{~g} / \mathrm{ha}$ dan penyiangan mekanis menyebabkan perubahan komposisi gulma pada 4 - 12 MSA, hal ini ditandai dengan nilai koefisien komunitas antara perlakuan yang dibandingkan $<75 \%$ (Tabel 10).

Hasil pengamatan 4 MSA, aplikasi herbisida pikloram + 2,4 D 57,5+225 g/ha - 172,5 +675 g/ ha dan penyiangan mekanis dibandingkan kontrol memiliki tingkat kesamaan komposisi gulma antara $33-55 \%$. Perlakuan herbisida pikloram $+2,4 \mathrm{D}$ dosis $143,75+562,5 \mathrm{~g} / \mathrm{ha}$ memiliki kesamaan komposisi gulma terendah yaitu $33 \%$. Jenis gulma yang mendominasi pada 4 MSA petak perlakuan herbisida pikloram $+2,4 \mathrm{D}$ dosis $143,75+562,5 \mathrm{~g} /$ ha adalah Dactyloctenium aegyptum, sedangkan pada petak kontrol didominasi oleh Ludwigia octovalvis. Aplikasi hebisida pikloram $+2,4 \mathrm{D}$ dosis $57,5+225 \mathrm{~g} / \mathrm{ha}-172,5+675 \mathrm{~g} / \mathrm{ha}$ menyebabkan terjadinya perubahan komposisi jenis gulma dari Ludwigia octovalvis menjadi Dactyloctenium aegyptum.

Hasil pengamatan 8 MSA, aplikasi herbisida pikloram + 2,4 D 57,5 + $225 \mathrm{~g} / \mathrm{ha}-172,5+675 \mathrm{~g} /$ ha dan penyiangan mekanis dibandingkan kontrol memiliki tingkat kesamaan komposisi gulma antara $25-75 \%$. Perlakuan herbisida pikloram $+2,4 \mathrm{D}$ dosis $143,75+562,5 \mathrm{~g} /$ ha memiliki kesamaan komposisi gulma terendah yaitu $25 \%$. Jenis gulma yang mendominasi pada 8 MSA petak perlakuan herbisida pikloram $+2,4 \mathrm{D}$ dosis $143,75+562,5 \mathrm{~g} /$ ha adalah Dactyloctenium aegyptum, sedangkan pada petak kontrol didominasi oleh Ludwigia octovalvis. Aplikasi hebisida pikloram $+2,4 \mathrm{D}$ dosis $57,5+225 \mathrm{~g} / \mathrm{ha}-172,5+675 \mathrm{~g} / \mathrm{ha}$ menyebabkan terjadinya perubahan komposisi jenis gulma dari Ludwigia octovalvis menjadi Dactyloctenium aegyptum.

Hasil pengamatan $12 \mathrm{MSA}$, aplikasi herbisida pikloram + 2,4 D 57,5 + $225 \mathrm{~g} / \mathrm{ha}-172,5+675 \mathrm{~g} /$ ha dan penyiangan mekanis dibandingkan kontrol memiliki tingkat kesamaan komposisi gulma antara $30-63 \%$. Perlakuan herbisida pikloram $+2,4 \mathrm{D}$ dosis $172,5+675 \mathrm{~g} /$ ha memiliki kesamaan komposisi gulma terendah yaitu $30 \%$. Jenis gulma

Tabel 11. Pengaruh herbisida pikloram $+2,4 \mathrm{D}$ terhadap populasi tanaman tebu

\begin{tabular}{|c|c|c|c|}
\hline \multirow{2}{*}{ Perlakuan } & 4 MSA & 8 MSA & \multirow{2}{*}{$\frac{12 \mathrm{MSA}}{\text { Data Asli }}$} \\
\hline & Data Asli & Data Asli & \\
\hline & & anaman $/ 21 \mathrm{~m} \mathrm{kai}$ & \\
\hline $\begin{array}{l}\text { Pikloram + 2,4 D } \\
57,5+225 \mathrm{~g} / \mathrm{ha}\end{array}$ & $99,75 \mathrm{ab}$ & $118,75 \quad b$ & $126,00 \mathrm{c}$ \\
\hline $\begin{array}{l}\text { Pikloram + 2,4 D } \\
86,25+337,5 \mathrm{~g} / \mathrm{ha}\end{array}$ & $89,50 \quad b$ & $116,75 \quad b$ & $139,00 \mathrm{bc}$ \\
\hline $\begin{array}{l}\text { Pikloram + 2,4 D } \\
115+450 \mathrm{~g} / \mathrm{ha}\end{array}$ & $91,50 \mathrm{ab}$ & $111,50 \quad b$ & $143,25 \mathrm{bc}$ \\
\hline $\begin{array}{l}\text { Pikloram +2,4 D } \\
143,75+562,5 \mathrm{~g} / \mathrm{ha}\end{array}$ & $94,25 \mathrm{ab}$ & $119,50 \quad b$ & $151,50 \mathrm{~b}$ \\
\hline $\begin{array}{l}\text { Pikloram + 2,4 D } \\
172,5+675 \mathrm{~g} / \mathrm{ha}\end{array}$ & $101,25 \mathrm{ab}$ & 151,25 a & $175,25 \mathrm{bc}$ \\
\hline Mekanis & $116,50 \mathrm{a}$ & 164,75 a & $213,75 \mathrm{a}$ \\
\hline Kontrol & 98,50 & $107,75 \quad b$ & $159,75 \mathrm{bc}$ \\
\hline BNT 5\% & 25,09 & 19,65 & 41,57 \\
\hline
\end{tabular}

Keterangan : Nilai tengah pada setiap kolom yang diikuti huruf yang sama tidak berbeda nyata menurut uji BNT pada taraf $5 \%$. 
Tabel 12. Pengaruh hebisida pikloram $+2,4 \mathrm{D}$ terhadap tinggi tanaman tebu

\begin{tabular}{|c|c|c|c|}
\hline \multirow{2}{*}{ Perlakuan } & 4 MSA & 8 MSA & \multirow{2}{*}{$\begin{array}{r}12 \text { MSA } \\
\text { Data Asli }\end{array}$} \\
\hline & Data Asli & Data Asli & \\
\hline & & $\ldots \ldots \ldots(\mathrm{cm}) \ldots$ & $\ldots \ldots \ldots \ldots \ldots \ldots$ \\
\hline $\begin{array}{l}\text { Pikloram + 2,4 D } \\
57,5+225 \mathrm{~g} / \mathrm{ha} \\
\text { Pikloram + 2,4 D }\end{array}$ & $134,00 \mathrm{~A}$ & $216,75 \mathrm{AB}$ & $232,25 \quad B$ \\
\hline $\begin{array}{l}86,25+337,5 \mathrm{~g} / \mathrm{ha} \\
\text { Pikloram }+2,4 \mathrm{D}\end{array}$ & $131,75 \mathrm{AB}$ & $225,50 \mathrm{AB}$ & $241,75 \mathrm{AB}$ \\
\hline $\begin{array}{l}115+450 \mathrm{~g} / \mathrm{ha} \\
\text { Pikloram }+2,4 \mathrm{D}\end{array}$ & $126,75 \mathrm{AB}$ & $215,00 \mathrm{AB}$ & $236,25 \mathrm{AB}$ \\
\hline $\begin{array}{l}143,75+562,5 \mathrm{~g} / \mathrm{ha} \\
\text { Pikloram }+2,4 \mathrm{D}\end{array}$ & $126,75 \mathrm{AB}$ & $215,50 \mathrm{AB}$ & $236,50 \mathrm{AB}$ \\
\hline $172,5+675 \mathrm{~g} / \mathrm{ha}$ & $135,00 \mathrm{~A}$ & $233,75 \mathrm{AB}$ & $253,25 \mathrm{~A}$ \\
\hline Mekanis & $137,75 \mathrm{~A}$ & $237,50 \mathrm{~A}$ & $254,25 \mathrm{~A}$ \\
\hline Kontrol & $122,25 \quad \mathrm{~B}$ & $209,00 \quad$ B & $236,25 \mathrm{AB}$ \\
\hline BNT 5\% & 11,70 & 25,26 & 20,54 \\
\hline
\end{tabular}

yang mendominasi pada 4 MSA petak perlakuan herbisida pikloram $+2,4 \mathrm{D}$ dosis $172,5+675 \mathrm{~g} / \mathrm{ha}$ adalah Dactyloctenium aegyptum, dan pada petak kontrol didominasi oleh Dactyloctenium aegyptum, namun walaupun gulma yang mendominasi nomor satu adalah gulma Dactyloctenium aegyptum pada petak perlakuan dosis $172,5+675 \mathrm{~g} /$ ha dan kontrol, nilai C menunjukkan bahwa apabila nilai kurang dari $75 \%$ maka keadaan gulma pada petak perlakuan tersebut berbeda. Aplikasi hebisida pikloram $+2,4$ $\mathrm{D}$ dosis $57,5+225 \mathrm{~g} / \mathrm{ha}-172,5+675 \mathrm{~g} / \mathrm{ha}$ menyebabkan terjadinya perubahan komposisi jenis gulma dari Ludwigia octovalvis menjadi Dactyloctenium aegyptum.

\subsection{Populasi Tanaman Tebu}

Perlakuan herbisida pikloram $+2,4 \mathrm{D}$ dosis 57,5 +225 sampai $172,5+675 \mathrm{~g} /$ ha memiliki populasi tanaman sama dengan perlakuan penyiangan mekanis pada 4 dan 12 MSA. Sementara pada 8 MSA perlakuan herbisida pikloram $+2,4 \mathrm{D}$ dosis $57,5+225$ sampai $143,75+562,5 \mathrm{~g} /$ ha memiliki populasi yang lebih rendah dibandingkan dengan perlakuan penyiangan mekanis pada 8MSA(Tabel11).

\subsection{Tinggi Tanaman Tebu}

Tabel 12 menunjukkan bahwa herbisida pikloram $+2,4 \mathrm{D}$ dosis 57,5 + 225 sampai 172,5+ $575 \mathrm{~g} /$ ha tidak mempengaruhi tinggi tanaman tebu pada 4, 8, dan 12 MSA. Tanaman tebu pada perlakuan herbisida campuran sama tingginya dengan perlakuan penyiangan mekanis, namun hanya pada perlakuan herbisida dosis $57,5+225 \mathrm{~g} /$ ha yang memiliki tanaman tebu terendah pada 12 MSA. Hal ini diduga disebabkan oleh persaingan tanaman tebu dengan gulma yang tidak dapat dikendalikan oleh herbisida campuran, sehingga sarana tumbuh yang seharusnya digunakan oleh tanaman dimanfaatkan oleh gulma yang ada.

\subsection{Fitotoksisitas Tanaman Tebu}

Tanaman tebu tidak menunjukkan gejala keracunan akibat aplikasi herbisida pikloram $+2,4$ D menunjukkan bahwa tidak terjadi keracunan pada tanaman tebu. Hal ini didukung dengan tinggi tanaman tebu pada perlakuan herbisida pikloram + $2,4 \mathrm{D}$ dosis $(57,5+225) \mathrm{g} /$ ha hingga $(172,5+675) \mathrm{g} /$ ha pada 4,8 , dan 12 MSA yang sama dengan perlakuan mekanis. Dengan kata lain herbisida pikloram $+2,4$ D tidak meracuni dan mempengaruhi pertumbuhan tanaman tebu. Hal ini sejalan dengan hasil penelitian Puspitasari dkk. (2013) bahwa tidak terdapat gejala keracunan pada tanaman tebu akibat aplikasi herbisida 2,4 D dosis formulasi 2 1/ha.

\section{KESIMPULAN}

Berdasarkan hasil penelitian dan pembahasan maka dapat disimpulkan herbisida pikloram $+2,4$ $\mathrm{D}$ dosis $(57,5+225) \mathrm{g} /$ ha hingga $(172,5+675) \mathrm{g} / \mathrm{ha}$ mampu mengendalikan pertumbuhan gulma total pada 4 minggu setelah aplikasi (MSA), gulma golongan daun lebar serta gulma dominan Richardia 
brasiliensis dan Ludwigia octovalvis pada 4, 8 dan 12 MSA, namun herbisida pikloram $+2,4 \mathrm{D}$ dosis $(57,5+225) \mathrm{g} /$ ha hingga $(172,5+675) \mathrm{g} /$ ha tidak mampu mengendalikan pertumbuhan gulma golongan rumput pada 4,8 , serta 12 minggu setelah aplikasi (MSA). Aplikasi hebisida pikloram +2,4 D dosis $(57,5+225) \mathrm{g} /$ ha hingga $(172,5+675) \mathrm{g} / \mathrm{ha}$ menyebabkan terjadinya perubahan komposisi gulma di pertanaman tebu. Herbisida 2,4 D + pikloram dosis $(57,5+225) \mathrm{g} /$ ha hingga $(172,5+675)$ $\mathrm{g} /$ ha tidak meracuni tanaman tebu.

\section{DAFTAR PUSTAKA}

Alfredo, N., S. Nanik, dan R. J. S. Dad. 2012. Efikasi Herbisida Pratumbuh Metil Metsufuron Tunggal dan Kombinasinya dengan 2,4 D, Ametrin, atau Diuron terhadap Gulma pada Pertanaman Tebu (Saccharum officinarum L.) Lahan Kering. Jurnal Agrotropika. Vol 17(1): 29 - 34..
Badan Pusat Statistik. 2017. Produksi Gula di Indonesia. http://www.bps.go.id. Diakses pada tanggal 12 januari 2018.

Moenandir, J. 1990. Fisiologi Herbisida. Buku Gulma II. Badan Penerbit CV. Rajawali Press. Jakarta.

Puspitasari, K., H. T. Sebayang, dan Guritno, B. 2013. Pengaruh Aplikasi Herbisida Ametrin dan 22,4 D dalam Mengendalikan Gulma Tanaman Tebu (Saccharum officinarum L.). Jurnal Produksi Tanaman. Vol 1 (2):72 - 80.

Sembodo, D. R. J. 2010. Gulma dan Pengelolaannya. Graha Ilmu. Yogyakarta. Sriyani, N. 2011. Mekanisme Kerja Herbisida. Bahan mata kuliah Herbsisida dan Lingkungan.Fakultas Pertanian, Universitas Lampung.

Tjitrosoedirdjo, S., I. H. Utomo dan J. Wiroatmodjo (Eds). 1984. Pengelolaan Gulma di Perkebunan. Kerjasama Biotrop Bogor PT Gramedia. Jakarta. 225 hlm. 